\title{
Determinants of personality in the scope of motivation for maintaining abstinence in the case of male alcohol-dependent individuals concluding therapy
}

\author{
Jan Chodkiewicz \\ Department of Health Psychology, Institute of Psychology, University of Lodz, Lodz, Poland
}

\section{BACKGROUND}

The results of numerous studies indicate strong associations of personality with the occurrence, and also with the treatment, of alcohol dependence. However, there is no agreement regarding the role of particular dimensions of temperament and character in the course of, and for the results of, alcohol rehabilitation therapy. The objective of the present research was to investigate the relationships between the dimensions of temperament and character as they are presented by Robert Cloninger and motivation for maintaining abstinence in the case of male alcohol-dependent individuals concluding the therapy.

\section{PARTICIPANTS AND PROCEDURE}

Eighty-nine male alcohol-dependent individuals, concluding alcohol rehabilitation therapy in an outpatient setting, were studied. The following research tools were applied: the Temperament and Character Inventory ( $\mathrm{TCl}$ ) of R. Cloninger in the Polish adaptation of E. Hornowska (2003), and the Motivation for Maintaining Abstinence Inventory, the author of which is M. Ziółkowski.

\section{RESULTS}

Two clusters, differing in the aspect of motivation for maintaining abstinence after the conclusion of the treatment, were distinguished: of individuals manifesting weaker motivation $(n=39)$ and those manifesting stronger motivation $(n=50)$. The patients with stronger motivation manifested the following major features: a lower level of harm avoidance, a higher level of reward dependence, and a higher level of cooperativeness.

\section{CONCLUSIONS}

Personality as it is presented by Cloninger manifests connections with motivation for maintaining abstinence. The research confirms the need for diagnosing addicted patients in the scope of temperament and character traits.

\section{KEY WORDS}

alcohol dependence; motivation for maintaining abstinence; temperament and character in accordance with Cloninger, the $\mathrm{TCl}$

CORResPonding Author - Prof. Jan Chodkiewicz, Department of Health Psychology, Institute of Psychology,

University of Lodz, 10/12 Smugowa Str., 91-433 Lodz, Poland, e-mail: janchodkiewicz@poczta.onet.pl AUthors' CONTRIBUtion - A: Study design - B: Data collection · C: Statistical analysis · D: Data interpretation .

E: Manuscript preparation $\cdot$ F: Literature search $\cdot$ G: Funds collection

TO CITE THIS ARTICLE - Chodkiewicz, J. (2014). Determinants of personality in the scope of motivation for maintaining

abstinence in the case of male alcohol-dependent individuals concluding therapy. Current Issues in Personality

Psychology, 2(4).

RECEIVED 24.09.2014 · REVIEWED 30.09.2014 · ACCEPTED 31.10.2014 · PUBLISHED 02.12.2014 


\section{BACKGROUND}

The results of numerous studies are in agreement in finding strong associations between personality and the developmental and clinical aspects of alcohol dependence, and also with the therapeutic ones (among others, Basiaux et al., 2001; Bętkowska-Korpała, 2012; Bottlender \& Soyka, 2005; Cooper, Agocha, \& Sheldon, 2000; Hornowska, 2003; Miller \& Lynam, 2013; Ruiz, Pincus, \& Dickinson, 2003). In accordance with the opinion of Miller and Lynam (2013), those associations are relevant, in particular, to such personality traits as neuroticism/negative emotionality, predisposition for antagonistic/aggressive interpersonal styles, and impulsiveness/behavioural disinhibition. The role of personality, significant and different from other variables being analysed in this area (for example, coping with stress, social support and the level of depression) consists, first and foremost, in the relative permanence of it, and, which is a consequence of that, a lower level of susceptibility to changes.

Research into the associations of personality with abusing alcohol and alcohol dependence conducted hitherto has chiefly been carried out on the basis of two models, namely on the Big Five Model of Costa and McCrae, and, significantly more frequently, the Psychobiological Conception of Personality of Robert Cloninger (Bętkowska-Korpała, 2012; Chodkiewicz, 2012; Hornowska, 2003, 2006). There is no need to make readers more acquainted with the conception of Cloninger, because it is extensively described in the literature of the subject. It should only be mentioned that, in accordance with that model, personality is composed of a genetically determined temperament understood as a biologically determined reaction pattern, and also of character, formed by the environment, and presented as the traits of an individual acquired in the course of development and connected with the perception of themselves (in particular, of objectives and values). Amongst the dimensions of temperament, the following were distinguished: novelty seeking, harm avoidance, reward dependence, and persistence. In the group of dimensions of character, the following were included: self-directedness, cooperativeness, and self-transcendence (Cloninger, Svrakic, \& Przybeck, 1993; Cloninger, 1997; Hornowska, 2003, 2006). It is worth emphasizing that in the research conducted since developing that conception, its presumptions concerning the biological foundation of three out of the four dimensions of temperament - novelty seeking, related to the dopaminergic system; harm avoidance, connected with the serotonergic system; and reward dependence, manifesting connections with the noradrenergic system (Cloninger, Sigvardsson, \& Bohman, 2000; Hornowska, 2003, 2006) - have been confirmed.

The research conducted for a number of years in the fields of addiction psychology and medicine on the basis of the conception of personality of Robert Cloninger has made it possible to arrive at a number of important conclusions. In that research, among others, associations between novelty seeking and the intensification of alcohol-related problems in the case of adolescents and young adults (among others, Chodkiewicz, 2010; Galen, Henderson, \& Whitman, 1996; George, Connor, Gullo, \& Young, 2010), and also differences in the scope of that dimension, as well as harm avoidance and self-directedness, between individuals addicted to alcohol and the control group (Syrek, Pełka-Wysiecka, Kucharska-Mazur, Sznabowicz \& Samochowiec, 2007, cf. also Perez $\&$ Mota, 2008), were proved. It was revealed as well that students taking narcotics manifest, as a major feature of themselves, a higher level of novelty seeking, and a lower level of persistence and of self-directedness, in comparison with their peers who neither take narcotics nor intend to do so (Chodkiewicz, 2007; Hornowska, 2003). The dimension of novelty seeking, which, on the basis of numerous studies, has come to be considered to be a significant risk factor for the occurrence and the permanence of the majority of addictions, was connected with the exacerbation of the alcohol problems as well (Andó et al., 2014), whereas self-directedness manifested negative associations with the occurrence of personality disorders in the case of alcoholics (Basiaux et al., 2001). A higher level of novelty seeking was also a major feature of alcoholics commencing addictive drinking early in comparison with those who started to drink intensively later (Dom, Hulsijn, \& Sabbe, 2006). In turn, individuals addicted to heroin manifested, as a major feature of themselves, even higher results in the scope of that dimension than alcoholics (Le Bon et al., 2004).

The analysis of the rich literature relevant to the relationships of personality as it is presented by Cloninger and behaviours connected with addiction indicates that the largest number of ambiguous, or even mutually exclusive, data are relevant to the course and the effects of alcohol rehabilitation therapy. A review of those controversies was presented elsewhere (Chodkiewicz, 2012, 2013b). Some of the results can be found in Table 1 .

As shown in Table 1, particularly significant differences between the obtained results concern a connection between temperament and character traits and maintaining abstinence/occurrence of relapses after the conclusion of the treatment. It can be seen that even in the case of the dimension most frequently referred to in the context of the resumption of drinking, i.e. novelty seeking, certain research confirms a significant role of that, whereas other studies exclude it. A similar situation is observed in the scope of another dimension of temperament frequently referred to in the problems being analysed - that of persistence. In turn, harm avoidance in certain stud- 
Table 1

Results of selected research into associations between temperament and character in accordance with the conception of Cloninger and the course and the effects of the treatment of alcohol-dependent individuals

\begin{tabular}{cl} 
Research & Results \\
\hline
\end{tabular}

The course of the therapy

Kravitz, Fawcett, McGuire, Kravitz, and Whitney, 1999

Arnau, Mondon, and Santacreu, 2008

Chodkiewicz, 2013b
A significant negative role of novelty seeking in the conclusion of the therapy by addicted male individuals.

A significant positive role of the following dimensions: persistence, selfdirectedness, and also ability to cooperate, in the progress of an alcohol rehabilitation therapy.

A significant positive role of harm avoidance, persistence and self-directedness in the conclusion of the therapy.

\section{Maintaining abstinence after the therapy/relapses of drinking}

Sellman, Mulder, Sullivan, and Joyce, 1997

Willinger et al., 2002

Meszaros et al., 1999

Chodkiewicz, 2013b

Andó et al., 2012

Evren et al., 2013

Müller, Weijers, Böning, and Wiesbeck, 2008
It is exclusively a low level of persistence that is the predictor of the resumption of drinking by addicted male individuals.

A high level of novelty seeking is the predictor of relapse in the case of male individuals; in the case of female individuals, the predictor is a low level of harm avoidance.

A high level of novelty seeking is the predictor of relapse in the case of male individuals.

A higher level of harm avoidance in the case of individuals maintaining abstinence after the therapy in comparison with those discontinuing abstinence. Also, differences in certain subdimensions of selfdirectedness and cooperativeness. The roles of novelty seeking and persistence were not confirmed.

Alcoholics after a longer period of abstinence in comparison with those after a shorter period of soberness manifested, as a major feature of themselves, a higher level of self-directedness and ability to cooperate, and a lower level of harm avoidance. The significances of novelty seeking and persistence were not confirmed.

It is exclusively a low level of self-directedness that is the predictor of relapse of drinking.

It is exclusively a low level of persistence that is the predictor of relapse. ies plays a positive role, and in some others a negative one. These differences are increased even further by different sizes of the groups studied (ranging from between ten and twenty individuals to several hundred of them), and also the application in them of two research tools that are operationalizations of the model of Cloninger (the Tridimensional Personality Questionnaire - TPQ, or, alternatively, a further version of that tool - the Temperament and Character Inventory - TCI). Furthermore, in some of the studies (for example, in the course of distinguishing the predictors of relapses) it was exclusively the TPQ or, alternatively, the TCI, that was applied, whereas in the remaining ones, different tools were applied together with those two (both for the research into personality, and into the accompanying variables alike).
The controversies briefly referred to above are arguments which support the claim that there is a need for conducting further research into the relationships between personality and the results of the treatment of alcohol-dependent individuals. The reason for that fact is that those studies may not only result in gaining more accurate knowledge about the functioning of addicted individuals, but also contribute to modifying therapeutic programmes, and, by doing that, increase the effectiveness of the treatment, which is still not satisfactory (cf. Chodkiewicz, 2012). However, it seems that those investigations should take into consideration not only direct associations of temperament and character with the results of the treatment in the form of maintaining (or, alternatively, a failure to maintain) abstinence, but also 
result in gaining knowledge about the relationships of personality with other variables important for the results of the treatment. It is only then that the development (or, alternatively, extension) of models taking into consideration a distinguished (direct and indirect) influence of numerous variables exerted upon the functioning of patients after the conclusion of alcohol rehabilitation therapy will be possible. It is worth pointing out that, in recent years, several such studies have been undertaken: among others, associations between temperament and character with the application of defence mechanisms in the case of alcoholics (Evren et al., 2013), the occurrence of a situation of a high risk of the discontinuation of abstinence (Chodkiewicz, Ziółkowski, \& Czarnecki, 2014), the quality of life in the case of addicted individuals (Evren, Dalbudak, Durkaya, Cetin, \& Evren, 2010), and the relationships of personality with another recognized factor increasing the risk of relapse, i.e. impulsiveness (Bozkurt et al., 2014), have been analyzed.

It was resolved that the research constituting the subject of this paper would attempt to answer the research question concerning relationships between the dimensions of temperament and character as they are presented by Cloninger, and motivation for maintaining abstinence in the case of male alcohol-dependent individuals. Deciding to research motivation and the correlates of it results from the fact, well documented by empirical research, that motivation (in particular, the internal one) is one of the strongest predictors of the results of psychotherapy, including in the case of alcohol-dependent individuals (cf. Chodkiewicz, 2012, 2013a; Cooper, 2010; Laudet \& Stanick, 2010). In spite of that, motivation has been devoted relatively little space in research into alcohol-dependent individuals to date; the symptom of that way of thinking is, in accordance with the opinion of Groshkova (2010), the fact that no coherent model including external and internal factors influencing the motivation and the changes in it in the case of alcoholics has been developed yet.

When the present research was being undertaken, a decision was made that attention would be focused on motivation for maintaining abstinence, because it is nothing else but maintaining continued soberness, which is one of the fundamental objectives of the therapy of addicted individuals (Beck, Wright, Newman, \& Liese, 2007; Mellibruda \& Sobolewska-Mellibruda, 2006). It had been resolved that motivation would be investigated at the moment of the conclusion of the treatment, agreeing with the opinion that, at the beginning of it, motivation is ambivalent, weak and/ or stemming from external factors, and, therefore, that it should be the object of work throughout the entire period of the therapy (Mellibruda \& Sobolewska-Mellibruda, 2006; Miller, 2009). However, is motivation for constantly maintaining abstinence, which is a major feature of patients upon the conclusion of the treatment, exclusively the effect of therapeutic work (and, possibly, participation in groups of Alcoholics Anonymous), or, perhaps, does it depend upon other factors as well? The analysis of the literature of the subject indicates that similar studies have not been conducted amongst alcoholics yet.

\section{CURRENT STUDY}

\section{PARTICIPANTS}

In order to answer the set question, research was conducted at the Municipal Center of the Prophylaxis and Treatment of Dependencies in Lodz, conducting therapy on the basis of the strategic-structural approach, dominating in Poland, and originating from the Minnesota strategic-structural model of presenting the problem (Mellibruda \& Sobolewska-Mellibruda, 2006). Eighty-nine male individuals aged from 24 to 67 years concluding the therapy in an outpatient setting were studied (the research was conducted in the final week of the therapy, lasting 3-4 months). The average age of the studied individuals was 44.83 years $(S D=10.67)$, and the average age of commencing problem drinking was $29.13(S D=10.79)$. Amongst the studied individuals, $69(77.52 \%)$ were living with their families (wife/children/parents), and the remaining ones were living solitary existences. An alcohol problem in the family of origin occurred in the case of 54 individuals (60.67\%). For 62 individuals (69.66\%), the therapy which they were concluding was the first one, whereas the remaining ones had undertaken one, or more, attempts to undergo therapy before. All the studied individuals fulfilled the criteria of alcohol dependence in accordance with ICD-10, which fact was confirmed by means of a psychiatric examination. Individuals who are cross-dependent, meaning both on alcohol and narcotics or gambling alike, individuals with changes in the central nervous system, and also undertaking the treatment on the basis of a court sentence, were excluded from the research.

\section{PROCEDURE}

The following tools of research were applied in the study:

The Temperament and Character Inventory (TCI) of R. Cloninger in the Polish adaptation of E. Hornowska (2003). This inventory is composed of 240 statements, which a studied individual describes as "True or False". The TCI measures the four dimensions of temperament - novelty seeking (reacting actively to new stimuli), harm avoidance (inhibiting activities in response to negative stimuli), reward dependence (maintaining behaviour in response to positive reinforcements) and persistence (ability to 
sustain an activity independently), and also three dimensions of character: self-directedness (ability to control one's own behaviour), cooperativeness (acceptance of the behaviours of other individuals) and self-transcendence (a dimension connected with spirituality). Apart from the 7 mentioned chief dimensions, the TCI consists of 24 subdimensions as well. The Polish version of this inventory has very good psychometric properties, comparable with the original version of that tool (Hornowska, 2003).

The Motivation for Maintaining Abstinence from Alcohol Inventory of M. Ziółkowski (1999). This method applies a tool which is composed of four questions in which the studied individuals select one of five (or, in the case of the first question, of six) possibilities, as the most compatible with their plans and objectives concerning drinking alcohol in the period of the following 12 months. The first question concerns the way of drinking alcohol as the current objective (answers ranging from 1 - complete abstinence, to 4 - controlled drinking, and 6 - the lack of plans concerning maintaining or, alternatively, not maintaining abstinence), the second question determines the importance of the objective being set (1 - completely unimportant, to 5 - the most important thing in my life), the third question determines the predicted difficulty in attaining the objective (1 - attaining it will not be difficult for me, to 5 - the most difficult thing in my life), and question 4 concerns self-confidence in the scope of the possibilities of attaining the objective ( 1 - I do not believe that the objective could be attained by me to 5 - The objective will certainly be attained by me). Answers to the questions are not summed up, but each of them is assessed separately. The inventory has psychometric properties, and it was applied within the frameworks of the research of the World Health Organization (WHO) under the supervision of Ziółkowski (1999).

In statistical analyses, the Statistica program was applied. In order to distinguish sub-groups that are homogeneous due to different aspects connected with motivation for maintaining abstinence, the analysis of the clusters with the application of the $k$-means method was applied. As well as that, the Student $t$-test and the analysis of variation were used in order to compare the distinguished clusters in the scope of the dimensions and the subdimensions of temperament and character distinguished by the Cloninger dimensions.

\section{RESULTS}

In the course of the first stage, the means obtained in the Motivation for Maintaining Abstinence from Alcohol Inventory were calculated. The results are presented in Table 2 .

As can be seen in Table 2, the studied individuals upon the conclusion of the therapy are oriented on maintaining abstinence rather than on controlled drinking, and that objective is a very important one for them; they consider it to be quite difficult to attain, but they have a relatively high level of self-confidence as far as attaining that objective is concerned.

The subsequent step was distinguishing, amongst the studied individuals, the sub-groups of patients varied in terms of various aspects relevant to motivation for maintaining abstinence. As a result of the application of cluster analysis with the application of the $k$-means method, the two homogeneous clusters were formed (the first cluster $=39$; the second one $n=50$ ). The clusters which were distinguished are presented in Figure 1, whereas the differences between them are presented in Table 3.

As presented in Table 3, the distinguished clusters differ statistically significantly in terms of all aspects concerning the motivation being analysed. The individuals belonging to the second cluster are definitely concentrated upon maintaining complete abstinence after the conclusion of the therapy; that objective is a very important one for them, and, even though it seems to them that it is difficult to attain, they are self-confident that they will be able to do it. Contrary to them, the individuals from the first cluster have unclear objectives as far as the future abstinence is concerned (they permit controlled drinking, or, alternatively, have no clearly defined objectives). Those objectives, in comparison with other goals in their lives, are not very important for them; simultaneously, they consider those objectives to be quite easy to attain, even though they do not have much self-confidence in their own ability to do it.

Table 2

The Motivation for Maintaining Abstinence from Alcohol Inventory: means and standard deviations for the group of studied male individuals concluding the therapy

\begin{tabular}{ccccc}
\hline & $M$ & Min & Max & $S D$ \\
\hline Abstinence - objective & 1.87 & 1.00 & 6.00 & 1.38 \\
Weight of the objective & 4.37 & 1.00 & 5.00 & 0.79 \\
Difficulty in attaining the objective & 3.83 & 1.00 & 5.00 & 1.21 \\
Self-confidence & 4.23 & 2.00 & 5.00 & 0.74 \\
\hline
\end{tabular}




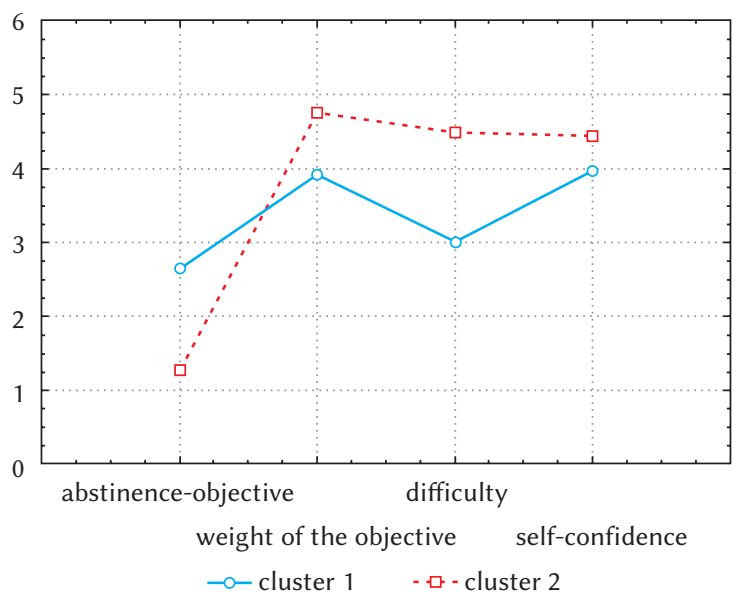

Figure 1. Clusters distinguished upon the conclusion of the therapy.

After distinguishing the sub-groups of addicted male individuals, differing in the aspect of motivation for maintaining abstinence, it was determined which of the dimensions and subdimensions of temperament and character differentiate the distinguished clusters from one another. The results are presented in Table 4.

As presented in Table 4, the distinguished clusters differ in the aspect of two of the four dimensions of temperament (and also in the aspect of two subdimensions) and one dimension (and also the subdimensions) of character. The individuals belonging to the first cluster (a major feature of whom is weaker motivation for maintaining abstinence after the therapy) in comparison with individuals from the second cluster manifest (in the case of temperament) a higher level of harm avoidance, are, therefore, more anxious, easily discouraged, uncertain and passive. As well as that, they are more pessimistic (a higher result in the HA 1 - perhaps, it was the reason why in the case of those individuals a lower level of self-confidence as far as attaining the objective is concerned was observed), and find it more difficult to recover after experienced unpleasant events. Those individuals also had higher levels of results in the dimension of reward dependence, which means that they are less sensitive and susceptible to messages from the environment, cool and distancing themselves, that they do not reveal their emotions, that they are more egocentric, and also that they find it more difficult to establish positive interpersonal relationships ( $\mathrm{RD}$ and RD 1).

In the case of characterological variables, the dimension connected with cooperativeness was revealed to be the one causing most differences (C, C 1, C 3, C 4 and C5). The comparison of the obtained clusters indicates that individuals belonging to the first group having lower results in that dimension and in the subdimensions of it are more concentrated upon themselves, less tolerant and patient, more critical towards other individuals, and also predisposed to manipulation. Such individuals may have no qualms about attempting to attain their own objectives, and be characterized by ruthlessness. Such a profile is compatible with a lower level of result in the responsibility subdimension of self-directedness (SD 1). Individuals having a low level of results in that subdimension manifest, as a major feature of themselves, blaming others for their own problems, and being unwilling to accept responsibility for their own behaviour (Hornowska, 2003).

Analysing the data obtained in the research, diversity in the scope of socio-demographic variables was calculated as well, taking into consideration the distinguished clusters. Those analyses revealed no differences between the clusters in the age of the patients (Student's $t=0.12$, not significant), the age of commencing problem drinking $(t=0.81$, not significant), residential arrangements (solitary or with the family) ( $\chi^{2}=0.25, d f=1$, not significant), the occurrence of alcoholism in the family of origin $\left(\chi^{2}=0.21\right.$, $d f=1$, not significant), or earlier commencement of undertaking alcohol rehabilitation therapy $\left(\chi^{2}=3.15\right.$, $d f=1$ and $p=.070)$.

Table 3

Comparison of the two clusters distinguished on the basis of the Motivation for Maintaining Abstinence from Alcohol Inventory

\begin{tabular}{|c|c|c|c|c|c|c|}
\hline & \multicolumn{2}{|c|}{$\begin{array}{c}\text { Cluster } 1 \\
n=39\end{array}$} & \multicolumn{2}{|c|}{$\begin{array}{c}\text { Cluster } 2 \\
n=50\end{array}$} & \multicolumn{2}{|c|}{ ANOVA } \\
\hline & $M$ & $S D$ & $M$ & $S D$ & $F$ & $p$ \\
\hline Abstinence - objective & 2.64 & 1.75 & 1.28 & 0.45 & 27.79 & $<.001$ \\
\hline Weight of the objective & 3.90 & 0.88 & 4.74 & 0.44 & 34.51 & $<.001$ \\
\hline $\begin{array}{l}\text { Difficulty in attaining } \\
\text { the objective }\end{array}$ & 3.00 & 1.26 & 4.48 & 0.65 & 51.88 & $<.001$ \\
\hline Self-confidence & 3.97 & 0.74 & 4.44 & 0.67 & 9.54 & $<.001$ \\
\hline
\end{tabular}


Table 4

Comparison of the clusters in the aspect of the dimensions and subdimensions of the TCI

\begin{tabular}{|c|c|c|c|c|c|c|}
\hline \multirow[t]{2}{*}{ Dimensions and subdimensions of the $\mathrm{TCl}$} & \multicolumn{2}{|c|}{$\begin{array}{c}\text { Cluster } 1 \\
n=39\end{array}$} & \multicolumn{2}{|c|}{$\begin{array}{c}\text { Cluster } 2 \\
n=50\end{array}$} & \multirow[t]{2}{*}{$t$} & \multirow[t]{2}{*}{$p$} \\
\hline & $M$ & $S D$ & $M$ & $S D$ & & \\
\hline \multicolumn{7}{|c|}{ Temperament } \\
\hline NS. Novelty seeking & 21.65 & 5.15 & 21.71 & 5.12 & -0.05 & .950 \\
\hline NS 1. Curiosity & 4.80 & 1.79 & 5.17 & 2.10 & -0.73 & .450 \\
\hline NS 2. Impulsiveness & 5.05 & 1.90 & 4.88 & 1.92 & 0.37 & .690 \\
\hline NS 3. Extravagance & 6.10 & 2.25 & 6.61 & 2.22 & -0.94 & .370 \\
\hline NS 4. Disorderliness & 5.70 & 2.05 & 5.06 & 1.94 & 1.35 & .180 \\
\hline HA. Harm avoidance & 21.30 & 6.60 & 17.50 & 7.54 & 2.11 & .036 \\
\hline HA 1. Pessimism & 6.25 & 2.38 & 4.56 & 2.25 & 3.06 & .002 \\
\hline HA 2. Fear of uncertainty & 4.90 & 2.27 & 4.31 & 2.00 & 1.18 & .230 \\
\hline HA 3. Social anxiety & 5.10 & 2.47 & 4.53 & 2.42 & 0.97 & .340 \\
\hline HA 4. Fatigability, asthenia & 5.05 & 2.44 & 4.10 & 2.59 & 1.52 & .130 \\
\hline RD. Reward dependence & 12.45 & 3.44 & 14.89 & 3.24 & -3.06 & .002 \\
\hline RD 1. Sentimentality & 5.95 & 1.90 & 6.94 & 1.85 & -2.18 & .031 \\
\hline RD 2. Attachment & 4.15 & 1.60 & 4.85 & 1.67 & -1.73 & .100 \\
\hline RD 3. Dependence & 2.35 & 1.14 & 3.21 & 1.26 & -1.85 & .060 \\
\hline P. Persistence & 3.40 & 2.19 & 4.05 & 1.77 & -1.44 & .150 \\
\hline \multicolumn{7}{|c|}{ Character } \\
\hline SD. Self-directedness & 20.00 & 8.54 & 22.58 & 7.61 & -1.37 & .190 \\
\hline SD 1. Responsibility & 3.40 & 2.41 & 4.40 & 1.94 & -2.03 & .039 \\
\hline SD 2. Purposefulness of action & 4.40 & 2.23 & 4.61 & 1.77 & -0.47 & .640 \\
\hline SD 3. Resourcefulness & 2.10 & 1.55 & 2.62 & 1.64 & -1.31 & .180 \\
\hline SD 4. Self-acceptance & 5.10 & 2.83 & 5.33 & 2.49 & -0.38 & .690 \\
\hline SD 5. Congruent second nature & 5.10 & 2.71 & 5.63 & 2.44 & -0.88 & .380 \\
\hline C. Cooperativeness & 24.80 & 6.62 & 29.32 & 6.61 & -2.81 & .006 \\
\hline C 1. Tolerance & 5.50 & 1.64 & 6.34 & 1.67 & -2.08 & .037 \\
\hline C 2. Empathy & 3.30 & 1.30 & 3.90 & 1.68 & -1.51 & .130 \\
\hline C 3. Helpfulness & 4.50 & 1.43 & 5.37 & 1.48 & -2.43 & .014 \\
\hline C 4. Compassion & 6.00 & 2.66 & 7.27 & 2.68 & -1.96 & .050 \\
\hline C5. Integrated conscience & 5.50 & 2.01 & 6.51 & 1.52 & -2.59 & .011 \\
\hline ST. Self-transcendence & 16.40 & 7.26 & 16.31 & 5.48 & 0.07 & .920 \\
\hline ST 1. Transcending the self & 6.05 & 2.96 & 5.59 & 2.06 & 0.85 & .390 \\
\hline ST 2. Transpersonal identification & 4.80 & 2.75 & 4.48 & 2.55 & 0.51 & .610 \\
\hline ST 3. Spiritual acceptance & 5.55 & 3.27 & 6.23 & 2.65 & -1.02 & .310 \\
\hline
\end{tabular}




\section{DISCUSSION}

The present research confirms the associations of temperament and character traits distinguished in the model of Robert Cloninger with motivation for maintaining abstinence, and, therefore, with one of the significant aspects connected with the results of the therapies of alcohol-dependent individuals (Chodkiewicz, 2013a). That means that they are part of a long list of studies (some of which were mentioned in the introduction to this paper) showing mutual correlations of the psychobiological theory of personality of Cloninger with the functioning of addicted individuals.

Simultaneously, due to the controversies already indicated, studying in more detail these changes the significant associations of which have been proved is worthwhile. Consequently, the patients belonging to the second cluster, and, therefore, the individuals who may be described as more motivated for maintaining lasting abstinence, manifest, as a major feature of themselves, a lower level of harm avoidance, which means that they are more courageous, self-controlled and optimistic (Hornowska, 2003). The obtained result is an interesting one, first and foremost, due to the ambiguous role of that dimension of temperament which has been proved previously. A low level of harm avoidance was, in accordance with the research of Willinger et al. (2002), a predictor of the resumption of drinking in the case of addicted female individuals, and therefore it had a negative role. Also my own research (Chodkiewicz, 2012, 2013b) showed an adverse role of low results obtained in the scope of that dimension (in the case of both sexes) in the scope of the conclusion of the therapy. A different result was obtained by Andó et al. (2012) - in their research, alcoholics after a longer period of abstinence manifested, as a major feature of themselves, a lower level of harm avoidance. In turn, the remaining studies did not show significance of that variable. Furthermore, numerous reports show positive associations of the dimension of harm avoidance with psychopathology, among others, depression, anxiety, and bipolar affective disorder, and also with intensification of the pain being experienced (among others, Hornowska, 2003; Kronström et al., 2011; Schilling et al., 2007). Attempting to explain such controversies in the scope of addicted individuals, it is possible to evoke the differences between the studied groups and objectives which were set in the studies. However, there are studies in which it was proved that the influence exerted by harm avoidance upon maintaining abstinence after the treatment was a suppressive one - a direct influence was bearing the sign opposite to that of the indirect one. The reason for that fact is that in those studies it was revealed that the above-mentioned dimension exerts a di- rect positive influence upon maintaining abstinence (a high level of harm avoidance by the relationship with anxiety, feeling guilty and exposing oneself to inhibits the consumption of psychoactive drugs), but, simultaneously, the influence exerted by that is a negative one as well because it lowers the level of another important variable - satisfaction with one's health (Chodkiewicz, 2012). Perhaps a similar situation occurs in the case of motivation, too. However, further research would be required to establish that; the research would have to concern the relationships of declared motivation for maintaining soberness with actually maintaining it. Therefore, one does not find it strange that there exists a negative association between pessimism (a subdimension of harm avoidance) with motivation for maintaining abstinence - individuals not having self-confidence in the possibility of attaining their own objectives have no confidence in being able to maintain soberness, either.

In the context of the correlations being discussed, the role of reward dependence seems to be easier to understand. As reported by Hornowska (2003), the individuals obtaining higher results in that dimension are more sensitive to social messages, and are more easily swayed by the views and opinions of those who constitute their milieu, too. Perhaps the situation is that such individuals find it easier to internalize the contents communicated both in the course of the therapy and also coming from their family and friends. Those contents (needless to say, if the family and friends of an individual are conscious of the core of alcoholism) are definitely concentrated upon maintaining continued abstinence; it is simultaneously assumed that it is a difficult choice, albeit a possible one. Furthermore, the majority of patients since the commencement of the therapy have been participating in meetings of Alcoholics Anonymous, at which they also come across a message claiming that it is necessary to maintain continued abstinence, and it may be useful to be more reward-dependent in that scope. The correctness of such reasoning may be proved as well by the fact that amongst individuals from the first cluster (having weaker motivation) a slightly larger percentage than in the second cluster was constituted by the patients who had made attempts to undergo successful therapy before, and who, however (since they had discontinued abstinence) had failed to internalize the contents communicated in them (the obtained result was at the level of a statistical tendency, $\chi^{2}=3.15, d f=1$ and $p=.070$; therefore, it requires further verification). Needless to say, similarly to what is the case as far as harm avoidance is concerned, the actual role of that dimension in maintaining continued soberness may be checked by conducting further research concerning the relationships: temperament-motivation-abstinence. It is worth pointing out that in the research conducted to date, the role of reward dependence has not been proved. The sig- 
nificance of that made clear in that study postulates the necessity of paying more attention to patients questioning the contents communicated to them in the course of the therapy, who are less sensitive to social messages (for example, feedback from the group and from therapists), and keeping oneself to oneself rather than seeking contacts with the group. Perhaps the mechanism of 'illusions and denials', which, in accordance with the opinion of Mellibruda (Mellibruda \& Sobolewska-Mellibruda, 2006), is one of the fundamental mechanisms of addiction, is connected with the temperamental dimension of addiction to reward, and, ipso facto, is in the case of certain patients much more difficult to change. Such a correlation is worth investigating in the future.

In the present studies, the significance of novelty seeking, and, therefore, of the dimension which is most frequently associated with behaviours having the character of a dependence, was not proved. Taking into consideration the strong associations of novelty seeking with impulsiveness, proved in the case of alcoholics (Bozkurt et al., 2014), that dimension, perhaps, is more connected with the behavioural aspect of relapses (for example, the discontinuation of abstinence in the situation of a high level of risk), and not the cognitive one (declaration of abstaining from alcohol). That also requires verification in further research.

Among characterological dimensions, the largest number of differences between the clusters was observed in cooperativeness. A positive role of that dimension in alcohol rehabilitation therapy and the results of it has been proved in the literature of the subject (Andó et al., 2012; Arnau et al., 2008). What is interesting, that dimension (measured with the application of the TCI as well) was also positively correlated with motivation for giving up smoking in the case of individuals addicted to nicotine (Bishry et al., 2012). A significant role of cooperativeness in the functioning of addicted individuals is also supported by the results of the research of Bętkowska-Korpała (2012), who proved that individuals resuming drinking in comparison with patients maintaining abstinence after the treatment manifest, as a major feature of the former, a lower level of results in the scope of two dimensions of personality measured with application of the NEO-FFI - amicability and conscientiousness. Both of those dimensions, as it was proved by Hornowska (2003), are strongly and positively correlated with cooperativeness alone. Strong $(r=.54)$ associations of cooperativeness with a temperamental dimension of reward dependence (Hornowska, 2003) were also proved; the mechanism of the relationships of both of the dimensions with motivation may, therefore, be a similar one.

The research did not prove an association between the dimension of self-directedness (the main result) and motivation for maintaining abstinence.
The aforementioned study into motivation for giving up smoking did not reveal such associations, either (Bishry et al., 2012). The role of that dimension (similarly to a temperamental dimension of persistence) is, perhaps, greater in a situation of introducing changes in life than in the case of planning them.

The last interesting result is the lack of associations between motivation and the dimensions of self-transcendence associated with spirituality. It is worth pointing out that all the studies conducted in that trend in research (including the, already mentioned, studies concerning motivation for giving up smoking) consistently show the lack of associations of that dimension with the behaviours connected with the course and the effects of the therapy of addicted individuals. That is interesting, because, for example, participation in the AA movement (and also certain therapeutic ways of presenting the problem) adopt the presumption of openness to spirituality. In the future, it will be recommendable to investigate those relationships with the application of other tools for researching spirituality.

In recapitulation, the present research indicates a number of correlations which are interesting, and, as it seems, worth further investigation. They confirm a significant role of personality in the course of the therapy of alcohol dependence, and they also indicate the need for diagnosing addicted patients in that field, as well as the need for modifying therapies on the basis of the obtained results. It is worth pointing out that all the authors of research into the role of temperament and character in the therapy of alcohol dependence, and the results of those studies (which are quoted in Table 1), postulate diagnosing addicted patients in the scope of the personality traits which those individuals have as well.

The research is restricted by concentration exclusively upon male individuals, and also the application of only one method for the objective of research into motivation. In future research, it will be worth paying attention to addicted female individuals, applying more complex tools for research into the motivation of addicted patients (for example, the Decisional Balance Scale of Velicer et al.), and also considering possible intermediary variables in the relationship between personality and motivation for maintaining abstinence.

\section{REFERENCES}

Andó, B., Must, A., Kurgyis, E., Szkaliczki, A., Drótos, G., Rózsa, S., Szikszay, P., Horváth, S., Janka, Z., \& Álmos, P. Z. (2012). Personality traits and coping compensate for disadvantageous decision-making in long-term alcohol abstinence. Alcohol and Alcoholism, 47, 18-24. 
Andó, B., Rózsa, S., Kurgyis, E., Szkaliczki, A., Demeter, I., Szikszay, P., Demetrovics, Z., Janka, Z., \& Álmos, P. Z. (2014). Direct and indirect symptom severity indicators of alcohol dependence and the personality concept of the biosocial model. Substance Use and Misuse, 49, 4418-4426.

Arnau, M. M., Mondon, S., \& Santacreu, J. J. (2008). Using the Temperament and Character Inventory (TCl) to Predict Outcome after Inpatient Detoxification during 100 Days of Outpatient Treatment. Alcohol and Alcoholism, 43, 583-588.

Basiaux, P., Le Bon, O., Dramaix, M., Massat, I., Souery, D., Mendlewicz, J., Pelc, I., \& Verbanck, P. (2001). Temperament and character inventory (TCI) personality profile and sub-typing in alcoholic patients: A controlled study. Alcohol and Alcoholism, 36, 584-587.

Beck, A., Wright, F., Newman, C., \& Liese, B. (2007). Terapia poznawcza uzależnień [Cognitive Therapy of Substance Abuse]. Kraków: Wydawnictwo Uniwersytetu Jagiellońskiego.

Bętkowska-Korpała, B. (2012). Osobowość w Modelu Wielkiej Piątki a utrzymywanie abstynencji od alkoholu przez rok od rozpoczęcia leczenia [Personality in the Big Five Model and maintaining abstinence after one year follow-up]. Psychiatria Polska, XLVI, 387-399.

Bishry, Z., Fekry, M., Shahawy, H. E., Soltan, M., Haroun, A., \& Moneim, D. A. (2012). The role of personality profile in the motivation to quit smoking. Middle East Current Psychiatry, 19, 206-213.

Bottlender, M., \& Soyka, M. (2005). Impact of different personality dimensions (NEO Five-Factor Inventory) on the outcome of alcohol-dependent patients 6 and 12 month after treatment. Psychiatry Research, 136, 61-67.

Bozkurt, M., Evren, C., Can, Y., Evren, B., Cetingok, S., \& Yilmaz, A. (2014). Relationships of personality dimensions with impulsivity in alcohol-dependent inpatient men. Nordic Journal of Psychiatry, 68, 316322.

Chodkiewicz, J. (2007). Zażywanie narkotyków przez młodzież. Znaczenie czynników temperamentalnych i charakterologicznych [The use of drugs among young people. The importance of temperamental and characterological factors]. Wychowanie Na Co Dzień, 10-11, 17-21.

Chodkiewicz, J. (2010). Nadużywanie alkoholu przez młodych mężczyzn i młode kobiety - znaczenie czynników temperamentalnych i charakterologicznych [The overuse of alcohol by young Man and Women. The importance of temperamental and dispositional factors]. Czasopismo Psychologiczne, 16, 181-188.

Chodkiewicz, J. (2012). Odbić się od dna? Rola jakości życia w przebiegu i efektach terapii osób uzależnionych od alkoholu [To strike against the Bottom and Begin to rise? The Quality of Life role In the course and effects of alcoholism therapy]. Łódź: Uniwersytet Łódzki.

Chodkiewicz, J. (2013a). Motywacja do leczenia i utrzymywania abstynencji a ukończenie terapii przez mężczyzn uzależnionych od alkoholu [Motivation for treatment and maintain abstinence and completion of therapy among men with alcohol dependence]. Alkoholizm i Narkomania, 26, 119-136.

Chodkiewicz, J. (2013b). Rola temperamentu i charakteru w ujęciu Roberta Cloningera w przebiegu i efektach terapii mężczyzn uzależnionych od alkoholu [The role of temperament and character in terms of Robert Cloninger theory in the course and treatment effects of alcohol dependent men]. In: J. Chodkiewicz, \& K. Gąsior (eds.), Wybrane zagadnienia z psychologii alkoholizmu [Selected issues of the psychology of alcoholism] (pp. 66-75). Warszawa: Difin.

Chodkiewicz, J., Ziółkowski, M., \& Czarnecki, D. (2014). Persönlichkeitsmodell nach Cloninger und Hochrisiko-Rückfallsituationen bei alkoholabhängigen Männern [Personality according to Robert Cloninger and high risk situations in men with alcohol dependence]. Suchttherapie, 15, 130-136.

Cloninger, R. (1997). A psychobiological model of personality and psychopathology. Journal of Psychosomatic Medicine, 37, 91-102.

Cloninger, R., Sigvardsson, S., \& Bohman, M. (2000). Typ I i Il alkoholizmu - uaktualnienie badań [Type I and II of alcoholism - an update]. In: Typologia alkoholizmu [Typology of alcoholism] (pp. 30-65). Warszawa: PARPA.

Cloninger, R., Svrakic, D. M., \& Przybeck, T. R. (1993). A psychobiological model of temperament and character. Archives of General Psychiatry, 50, 975990.

Cooper, M. L. (2010). Efektywność psychoterapii i poradnictwa psychologicznego [Essential Research Findings In Counselling and Psychotherapy. The Facts are Friendly]. Warszawa: Instytut Psychologii Zdrowia PTP.

Cooper, M. L., Agocha, V. B., \& Sheldon, M. S. (2000). A Motivational Perspective on Risky Behaviors: The Role of Personality and Affect Regulatory Processes. Journal of Personality, 68, 1059-1088.

Dom, G., Hulsijn, W., \& Sabbe, B. (2006). Differences in impulsivity and sensation seeking between early- and late-onset alcoholics. Addictive Behaviors, 31, 298-308.

Evren, C., Dalbudak, E., Durkaya, M., Cetin, R., \& Evren, B. (2010). Interaction of life quality with alexithymia, temperament and character in male alcohol-dependent inpatients. Drug and Alcohol Review, 29, 177-183.

Evren, C., Yigiter, S., Bozkurt, M., Cagil, D., Ozcetinkaya, S., Can, Y., \& Mutlu, E. (2013). Personality Dimensions and Defense Styles That are Related with Relapse During 12 Month Follow-up in Male 
Alcohol Dependents. Düşünen: The Journal of Psychiatry and Neurological Sciences, 26, 248-257.

Galen, L. W., Henderson, M. J., \& Whitman, R. D. (1996). The utility of novelty seeking, harm avoidance, and expectancy in the prediction of drinking. Addictive Behaviour, 22, 93-106.

George, S. M., Connor, J. P., Gullo, M. J., \& Young, R. M. (2010). A prospective study of personality features predictive of early adolescent alcohol misuse. Personality and Individual Differences, 49, 204-209.

Groshkova, T. (2010). Motivation in substance misuse treatment. Addiction Research and Theory, 18, 494-510.

Hornowska, E. (2003). Temperamentalne uwarunkowania zachowania [Temperamental determinants of behaviour]. Poznań: Bogucki Wydawnictwo Naukowe.

Hornowska, E. (2006). Uzależnienia a temperament. Wokół temperamentalnego czynnika ryzyka uzależnień [Addictions and temperament. Around temperamental risk factor for substance abuse]. In: L. Cierpiałkowska (ed.), Oblicza wspótczesnych uzależnień [Faces of contemporary addiction] (pp. 43-73). Poznań: Wydawnictwo UAM.

Kravitz, H. M., Fawcett, J., McGuire, M., Kravitz, G. S., \& Whitney, M. (1999). Treatment Attrition Among Alcohol-Dependent Men: Is It Related to Novelty Seeking Personality Traits? Journal of Clinical Psychopharmacology, 19, 51-56.

Kronström, K., Salminen, J. K., Hietala, J., Kajander, J., Vahlberg, T., Markkula, J., Rasi-Hakala, H., \& Karlsson, H. (2011). Personality traits and recovery from major depressive disorder. Nordic Journal of Psychiatry, 65, 52-57.

Laudet, B. A., \& Stanick, V. (2010). Predictors of motivation for abstinence at the end of outpatient substance abuse treatment. Journal of Substance Abuse Treatment, 38, 317-332.

Le Bon, O., Basiaux, P., Streel, E., Tecco, J., Hanak, C., Hansenne, M., Ansseau, M., Pelc, I., Verbanck, P., \& Dupont, S. (2004). Personality profile and drug of choice: A multivariate analysis using Cloninger's $\mathrm{TCl}$ on heroin addicts, alcoholics, and a random population group. Drug and Alcohol Dependence, 73, 175-182.

Mellibruda, J., \& Sobolewska-Mellibruda, Z. (2006). Integracyjna psychoterapia uzależnień. Teoria i praktyka [The integrative psychotherapy of addictions. Theory and practice]. Warszawa: IPZ.

Meszaros, K., Lenzinger, E., Hornik, K., Fureder, T., Willinger, U., Fischer, G., Schonbeck, G., \& Aschauer, H. (1999). The tridimensional personality questionnaire as a predictor of relapse in detoxified alcohol dependents. Alcoholism, Clinical and Experimental Research, 23, 483-486.

Miller, W. R. (2009). Wzmacnianie motywacji do zmiany [Enhancing Motivation for Change in Substance Use Disorder Treatment]. Warszawa: PARPAMEDIA.
Miller, J. D., \& Lynam, D. R. (2013). Personality and Addiction: A Critical Review of Assessment Approaches. In: J. MacKillop, \& H. de Wit (eds.), The Wiley-Blackwell Handbook of Addiction Psychopharmacology (pp. 111-133). New York: John Wiley \& Sons.

Müller, S. E., Weijers, H. G., Böning, J., \& Wiesbeck, G. A. (2008). Personality traits predict treatment outcome in alcohol-dependent patients. Neuropsychobiology, 57, 159-164.

Perez, P. P., \& Mota, R. G. (2008). Personality differences between subjects with substance addiction and subjects from the general population. Study with TCl-R of clinical cases with matched controls. Adicciones, 20, 251-261.

Ruiz, M. A., Pincus, A. L., \& Dickinson, K. A. (2003). NEO PI-R Predictors of alcohol use and alcohol-related problems. Journal of Personality Assessment, 3, 226-236.

Schilling, G., Bausch, C., Nadstawek, J., Wartenberg, H. C., Wegener, I., Geiser, F., Imbierowicz, K., \& Liedtke, R. (2007). Temperament and character personality profiles and personality disorders in chronic pain patients. Pain, 133, 197-209.

Sellman, J. D., Mulder, R. T., Sullivan, P. F., \& Joyce, P. R. (1997). Low persistence predicts relapse in alcohol dependence following treatment. Journal of Studies on Alcohol, 58, 257-263.

Syrek, S., Pełka-Wysiecka, J., Kucharska-Mazur, J., Sznabowicz, M., \& Samochowiec, J. (2007). Różnice w wymiarach osobowości oceniane inwentarzem TCl: Anonimowych Alkoholików, pacjentów hospitalizowanych z rozpoznanym ZZA i grupą kontrolną [Differences in personality traits measured by $\mathrm{TCl}$ among alcoholics participated in Anonymous Alcoholics, treated in a hospital and healthy controls]. Wiadomości Psychiatryczne, 10, 13-19.

Willinger, U., Lenzinger, E., Hornik, K., Fischer, G., Schönbeck, G., Aschauer, H. N., \& Meszaros, K. (2002). Anxiety as predictor of relapse in detoxified alcohol-dependent patients. Alcohol and Alcoholism, 37, 609-612.

Ziółkowski, M. (1999). Ocena skuteczności farmakoterapii w zapobieganiu nawrotowi picia u mężczyzn uzależnionych od alkoholu [Evaluation of the efficacy of pharmacotherapy in the prevention of relapse in alcohol dependence men]. Praca habilitacyjna. Bydgoszcz: Wydawnictwo Akademii Medycznej im. Ludwika Rydygiera. 